\title{
Second hand smoke exposure in workplace by job status and occupations
}

\author{
Hyunhee Park ${ }^{1,2^{*}} \mathbb{D}$, Sung-il Cho $^{2}$ and Changhun Lee ${ }^{1}$
}

\begin{abstract}
Background: The objective of this study is to evaluate the risk of exposure to second hand smoke (SHS) during working hours by job status and occupation.

Methods: Using the 4th Korean Working Conditions Survey (KWCS), 49,674 respondents who answered the question about SHS were studied. A chi-square test was carried out to determine whether there is a significant different in SHS exposure frequency by general and occupational characteristics and experience of discrimination at work and logistic regression analysis was carried out to identify the risk level of SHS exposure by variables.

Results: In this study, we found that male workers in their 40s and 50s, workers employed in workplaces with fewer than 50 employees, daily workers, and people working outdoors had a higher rate of exposure to SHS than the others. The top five occupations with the highest SHS exposure were construction and mining-related occupations, metal core-makers-related trade occupations, wood and furniture, musical instrument, and signboardrelated trade occupations, transport and machine-related trade occupations, transport and leisure services occupations. The least five exposed occupations were public and enterprise senior officers, legal and administrative professions, education professionals, and health, social welfare, and religion-related occupations.

Conclusion: Tobacco smoke is a significant occupational hazard. Smoking ban policy in the workplace can be a very effective way to reduce the SHS exposure rate in the workplace and can be more effective if specifically designed by the job status and various occupations.
\end{abstract}

Keywords: Second hand smoke exposure, Job status, Occupations, Smoking ban

\section{Background}

Second hand smoke (SHS), which is exposure to smoke from cigarette butts or smoke exhaled by smokers, is itself a Group 1 carcinogen for the human as classified by the International Agency for Research on Cancer (IARC). Exposure to SHS is known to be associated with respiratory and cardiovascular diseases as well as anxiety disorders, mental health, and psychological stress [1].

According to the National Health Statistics in Korea for 2015 [2], the current indoor SHS exposure rate of nonsmokers at work was $26.8 \%$, remarkably high compared with at home, which is $8.2 \%$. From OECD (Organization for Economic Cooperation and Development) data [3], the

\footnotetext{
* Correspondence: bioaerosol@kosha.or.kr

${ }^{1}$ Work Environment Research Bureau, Occupational Safety and Health Research Institute, 400, Jongga-ro, Jung-gu, Ulsan, Republic of Korea

${ }^{2}$ Department of Public Health Science, Graduate School of Public Health, and Institute of Health and Environment, Seoul National University, 1 Gwanak-ro, Gwanak-qu, Seoul 08826, Republic of Korea
}

smoking rate for Korean males aged more than 15 was $31.4 \%$ as of 2015 , which was the third highest rank among OECD countries. The Korean government has implemented a policy of smoking bans in public places for many years, but that smoking policy only applies with a workplace more than $1000 \mathrm{~m}^{2}$ in total area [4]. For that reason, the workplace is still at a high rate of SHS exposure and could be the environment that can be improved further in SHS exposure reduction.

From 1999 to 2002 US NHANES (National Health and Nutrition Examination Survey) data, there have been dramatic reduction in the serum cotinine levels caused by successful smoking-free laws [5]. Although SHS exposure rates are declining, the workplace remains a significant source of SHS exposure [6,7]. Working adults spend most of their time at workplace and for those non-smokers, the workplace may be the major source of provider to SHS exposure [8]. In the German

(c) The Author(s). 2019 Open Access This article is distributed under the terms of the Creative Commons Attribution 4.0 International License (http://creativecommons.org/licenses/by/4.0/), which permits unrestricted use, distribution, and reproduction in any medium, provided you give appropriate credit to the original author(s) and the source, provide a link to the Creative Commons license, and indicate if changes were made. The Creative Commons Public Domain Dedication waiver (http://creativecommons.org/publicdomain/zero/1.0/) applies to the data made available in this article, unless otherwise stated. 
study, More than $40 \%$ of non-smokers reported experiencing SHS at work [9]. Workplace smoking is an occupational health hazard and a smoking ban policy at the workplace is the best option to reduce SHS [10]. More than $50 \%$ of European countries enforce non-smoking regulations at work and the other European countries also partially restrict smoking at work. In the Netherlands, the comparison of SHS exposure rates before and after the implementation of the smoking ban policy in the workplace showed that the SHS exposure rate decreased from 70.7 to $51.9 \%$. However, the rate of SHS exposure is still high in the Netherlands even after the smoking ban at work, because of a high-risk group for smoking such as males and low-educated workers [11].

To reinforce the appropriated non-smoking policy at workplace, it is important to identify priority group to implement such as vulnerable job status and occupations to SHS exposure. In this study, we evaluated the risk of exposure to tobacco smoke by others during working hours by job status, experience of discrimination at work and occupation using the data of the 4th Korean Working Conditions Survey (KWCS).

\section{Methods}

\section{Study subjects}

This study used data from the 4th Korean Working Conditions Survey (KWCS), which was conducted between June and September 2014 on employed workers by the Occupational Safety and Health Research Institute (OSHRI) affiliated under the Ministry of Employment and Labor. The KWCS selected individuals who satisfied criteria for the definition of "economically active population" conducted one-on-one interviews at their home by a professional interviewer. The total sample of 50,007 persons, 15 years or older participated in this survey. The data used in this study are from 49,674 respondents who answered the question "Are you exposed at work to tobacco smoke from other people?”

\section{Variables selected for analysis}

The dependent variable was assessed to evaluate the risk of exposure to SHS by a question, "Are you exposed at work to tobacco smoke from other people?" Respondents answered on a seven-point scale of SHS exposure frequency; the choices were (in terms of all of the working time), "all", "almost", "3/4", "half", "1/4", "almost never", and "never". For chi-square test, exposure to SHS in workplace was categorized into 3 group; "over $1 /$ 4 workhours" (all $\sim 1 / 4$ ), "almost never" and "never". For logistic regression exposure to SHS in workplace was categorized into 2 group; "over $1 / 4$ workhours" (all $\sim 1 /$ 4) or "less than 1/4" (almost never and never). The rate of exposure to SHS for more than $1 / 4$ of workhours
(ESQ rate) was used to compare the SHS exposure by independent variables.

Independent variables included information on gender ("male" and "female"), age group ( " $\leq 39$ ", "40-49", "50-59" and " $\geq 60$ "), job status ("self-employed without workers", "self-employed with workers", "wage workers (employees)", "unpaid family worker" and "other workers"), type of wage worker ("permanent workers", "temporary workers" and "daily workers"), wage provider ("workplace", "a dispatcher" and "service provider"), Company size as number of workers in workplace ( $\leq 49$ ", " $50-299$ " and " $\geq 300$ "), type of workplace ("employer's place of business", "customer's place of business", "in the case of transportation as cars", "outdoor (construction, field/etc)", "my home" and "others"), job category ("manager", "specialist", "technician and associate export", "office worker", "service worker", "sales worker", "experts in agriculture and forestry fishing", "functional person and related person", "machine operator and assembly worker", "laborer" and "soldier"), and night working days in a month ( " $\leq 9$ ", " $10-19$ " and " $\geq 20$ ").

The item designed to evaluate the experience of discrimination at the workplace was used as a variables for the effect of exposure to SHS. The question is "During the past 12 months, did you experience to discrimination at your workplace related to age, race, nationality, gender, religion, disability, sexual orientation, academic group, region of origin, or employment status?" Respondents answered to the question about discrimination with 'yes' or 'no'.

The occupational categories of respondents were classified according to the Korean Standard Classification of Occupation (KSCO by National Statistical Office) and classified into occupational groups (52 groups, classification code: 2 digits) and detailed occupation (415 groups, classification code: 4 digits).

\section{Statistical analysis}

Data were analyzed using PASW version 18.0 (SPSS Inc., Chicago, IL, USA). Weight is applied when conducting statistical analysis based on the results of the "economically active population survey (EAPS)" in 2014 conducted by National Statistical Office. A chi-square test was carried out to determine whether there is a significant different between SHS exposure frequency by general and occupational characteristics and experience of discrimination at work and logistic regression analysis was carried out to identify the risk level of SHS exposure by variables.

\section{Results}

\section{General characteristics of population}

The sample characteristics are described in Table 1. Of the total 49,674 respondents, $57.8 \%$ were male and $36.9 \%$ were under the age of 39 which was the largest 
Table 1 General characteristics of the study subjects

\begin{tabular}{|c|c|c|c|c|c|}
\hline \multirow[t]{2}{*}{ Variables } & \multirow[t]{2}{*}{$\mathrm{n}$} & \multicolumn{3}{|c|}{ Exposure to SHS in Workplace (Number (\%)) } & \multirow[t]{2}{*}{$p$-value } \\
\hline & & Over $1 / 4$ workhours & Almost never & Never & \\
\hline \multicolumn{6}{|l|}{ Gender } \\
\hline Male & $28,732(57.8 \%)$ & $4587(16.0)$ & $9163(31.9)$ & $14,982(52.1)$ & \multirow[t]{2}{*}{$p<0.01$} \\
\hline Female & $20,942(42.2 \%)$ & $1441(6.9)$ & $5939(28.4)$ & $13,562(64.8)$ & \\
\hline \multicolumn{6}{|l|}{ Age(yrs) } \\
\hline$\leq 39$ & $18,351(36.9 \%)$ & $1661(9.1)$ & $5341(29.1)$ & $11,349(61.8)$ & \multirow[t]{4}{*}{$p<0.01$} \\
\hline $40-49$ & $12,958(26.1 \%)$ & $1777(13.7)$ & $3929(30.3)$ & $7252(56.0)$ & \\
\hline $50-59$ & $11,348(22.8 \%)$ & $1698(15.0)$ & $3608(31.8)$ & $6042(53.2)$ & \\
\hline$\geq 60$ & 7017 (14.1\%) & $892(12.7)$ & $2224(31.7)$ & $3901(55.6)$ & \\
\hline \multicolumn{6}{|l|}{ Job status } \\
\hline Self-employed without workers & $8058(16.2 \%)$ & $915(11.4)$ & $2449(30.4)$ & $4694(58.3)$ & \multirow[t]{5}{*}{$p<0.01$} \\
\hline Self-employed with workers & 3012 (6.1\%) & $522(17.3)$ & $913(30.3)$ & $1577(52.4)$ & \\
\hline Wage workers (employees) & $36,156(72.8 \%)$ & $4344(12.0)$ & $10,956(30.3)$ & $20,856(57.7)$ & \\
\hline Unpaid family worker & 2417 (4.9\%) & $244(10.1)$ & $767(31.7)$ & $1406(58.2)$ & \\
\hline Other workers & $27(0.1 \%)$ & $3(11.1)$ & $14(51.9)$ & $10(37.0)$ & \\
\hline \multicolumn{6}{|l|}{ Type of wage workers } \\
\hline Permanent workers & $27,279(76.0 \%)$ & $2900(10.6)$ & $8459(31.0)$ & $15,920(58.4)$ & \multirow[t]{3}{*}{$p<0.01$} \\
\hline Temporary workers & $6083(16.9 \%)$ & $722(11.9)$ & $1709(28.1)$ & $3652(60.0)$ & \\
\hline Daily workers & $2551(7.1 \%)$ & $675(26.5)$ & $716(28.1)$ & $1160(45.5)$ & \\
\hline \multicolumn{6}{|l|}{ Wage_provider } \\
\hline Work place & $33,503(94.7 \%)$ & $3796(11.3)$ & $10,178(30.4)$ & $19,529(58.3)$ & \multirow[t]{3}{*}{$p<0.01$} \\
\hline A dispatcher & $673(1.9 \%)$ & $104(15.5)$ & $202(30.0)$ & $367(54.5)$ & \\
\hline Service provider & $1213(3.4 \%)$ & $345(28.4)$ & $340(28.0)$ & $528(43.5)$ & \\
\hline \multicolumn{6}{|l|}{ Company size (Number of workers in workplace) } \\
\hline$\leq 49$ & $38,891(79.7 \%)$ & $4976(12.8)$ & $11,531(29.6)$ & $22,384(57.6)$ & \multirow[t]{3}{*}{$p<0.01$} \\
\hline $50-299$ & $6874(14.1 \%)$ & $670(9.7)$ & $2290(33.3)$ & $3914(56.9)$ & \\
\hline$\geq 300$ & $3011(6.2 \%)$ & $254(8.4)$ & $995(33.0)$ & $1762(58.5)$ & \\
\hline \multicolumn{6}{|l|}{ Type of workplace } \\
\hline Employer's place of business & $37,873(76.7 \%)$ & $3949(10.4)$ & $11,486(30.3)$ & $22,438(59.2)$ & \multirow[t]{6}{*}{$p<0.01$} \\
\hline Customer's place of business & 4107 (8.3\%) & $694(16.9)$ & $1193(29.0)$ & $2220(54.1)$ & \\
\hline In the case of transportation such as cars & $1388(2.8 \%)$ & $258(18.6)$ & $507(36.5)$ & $623(44.9)$ & \\
\hline Outdoor (construction site, field / etc.) & $5304(10.7 \%)$ & $1039(19.6)$ & $1661(31.3)$ & $2604(49.1)$ & \\
\hline My house & $533(1.1 \%)$ & $31(5.8)$ & $117(22.0)$ & $385(72.2)$ & \\
\hline Others & $199(0.4 \%)$ & $16(8.0)$ & $52(26.1)$ & $131(65.8)$ & \\
\hline \multicolumn{6}{|l|}{ Job Category } \\
\hline Manager & $1354(2.7 \%)$ & $176(13.0)$ & $421(31.1)$ & $757(55.9)$ & \multirow[t]{9}{*}{$p<0.01$} \\
\hline Specialist & $3759(7.6 \%)$ & $149(4.0)$ & $930(24.7)$ & $2680(71.3)$ & \\
\hline Technician and Associate Expert & $2505(5.0 \%)$ & $279(11.1)$ & $797(31.8)$ & $1429(57.0)$ & \\
\hline Office worker & $10,545(21.2 \%)$ & $746(7.1)$ & $3061(29.0)$ & $6738(63.9)$ & \\
\hline Service worker & $7666(15.4 \%)$ & $874(11.4)$ & $2140(27.9)$ & $4652(60.7)$ & \\
\hline Salesperson & $7532(15.2 \%)$ & $695(9.2)$ & $2115(28.1)$ & $4722(62.7)$ & \\
\hline Experts in agriculture and forestry fishing & $2951(5.9 \%)$ & $213(7.2)$ & $1014(34.4)$ & $1724(58.4)$ & \\
\hline Functional Person and Related Person & 4492 (9.0\%) & $1101(24.5)$ & $1572(35.0)$ & $1819(40.5)$ & \\
\hline Machine Operator and Assembly Worker & $3349(6.7 \%)$ & $733(21.9)$ & $1281(38.3)$ & 1335 (39.9) & \\
\hline
\end{tabular}


Table 1 General characteristics of the study subjects (Continued)

\begin{tabular}{|c|c|c|c|c|c|}
\hline \multirow[t]{2}{*}{ Variables } & \multirow[t]{2}{*}{$\mathrm{n}$} & \multicolumn{3}{|c|}{ Exposure to SHS in Workplace (Number (\%)) } & \multirow[t]{2}{*}{$p$-value } \\
\hline & & Over $1 / 4$ workhours & Almost never & Never & \\
\hline Laborer & $5416(10.9 \%)$ & $1049(19.4)$ & $1719(31.7)$ & $2648(48.9)$ & \\
\hline Soldier & $83(0.2 \%)$ & $4(4.8)$ & $46(55.4)$ & $33(39.8)$ & \\
\hline \multicolumn{6}{|c|}{ Occasionally need to wear personal protective equipment } \\
\hline Yes & $12,071(24.4 \%)$ & $2709(22.4)$ & $4116(34.1)$ & $5246(43.5)$ & \multirow[t]{2}{*}{$p<0.01$} \\
\hline No & $37,353(75.6 \%)$ & $3291(8.8)$ & $10,899(29.2)$ & $23,163(62.0)$ & \\
\hline \multicolumn{6}{|c|}{ Night working days in a month } \\
\hline$\leq 9$ & $2896(46.0 \%)$ & $518(17.9)$ & $874(30.2)$ & $1504(51.9)$ & \multirow[t]{3}{*}{$p<0.01$} \\
\hline $10-19$ & 2137 (34.0\%) & $392(18.3)$ & 763 (35.7) & $982(46.0)$ & \\
\hline$\geq 20$ & $1256(20.0 \%)$ & $361(28.7)$ & $343(27.3)$ & $552(43.9)$ & \\
\hline
\end{tabular}

age group. The number of wage workers was 36,156 $(72.8 \%)$ and number of respondents to the question about "wage worker type" and "wage provider" were 35,913 and 35,389 respectively. Of the respondents, $76.0 \%$ were permanent (regular) workers, $16.9 \%$ were temporary workers, and $7.1 \%$ were daily workers, respectively. Of the respondents, $94.7 \%$ were provided wage from workplace. By the size of the workplace,
$79.7 \%$ were employed at a workplace with less than 50 employees. In the major categories of occupation, the office workers were the largest, followed by the service workers, the sales workers, and the simple laborers.

From the chi-square test, the variables that showed significant differences in the exposure to SHS were gender, age, occupation status, wage provider, the size of the workplace, type of workplace, job category, whether to

Table 2 Multiple logistic analysis of factors affecting secondhand smoke exposure in workplace

\begin{tabular}{|c|c|c|}
\hline Dependent variables & Adjusted OR (Odds Ratio) & 95\% Cl (Confidence Interval) \\
\hline \multicolumn{3}{|l|}{ Sex (reference: Female) } \\
\hline Male & $4.107^{* *}$ & $3.461 \sim 4.874$ \\
\hline \multicolumn{3}{|l|}{ Age (reference: $\leq 39$ ) } \\
\hline $40-49$ & $1.551^{* *}$ & $1.348 \sim 1.785$ \\
\hline $50-59$ & $1.529^{* *}$ & $1.319 \sim 1.772$ \\
\hline$\geq 60$ & 1.116 & $0.916 \sim 1.360$ \\
\hline \multicolumn{3}{|c|}{ Number of workers in workplace (reference: $\geq 300$ ) } \\
\hline$\leq 49$ & $2.114^{* *}$ & $1.721 \sim 2.595$ \\
\hline $50-300$ & $1.545^{* *}$ & $1.232 \sim 1.937$ \\
\hline \multicolumn{3}{|l|}{ Status (reference: Permanent workers) } \\
\hline Temporary workers & 1.130 & $0.957 \sim 1.334$ \\
\hline Daily workers & $1.318^{* *}$ & $1.102 \sim 1.575$ \\
\hline \multicolumn{3}{|c|}{ Occasionally need to wear personal protective equipment (reference No) } \\
\hline Yes & 1.132 & $0.942 \sim 1.359$ \\
\hline \multicolumn{3}{|c|}{ Wage_Provider (reference: Work place (last week's work place)) } \\
\hline A dispatcher & 1.140 & $0.814 \sim 1.596$ \\
\hline Service provider & $1.736^{* *}$ & $1.401 \sim 2.149$ \\
\hline \multicolumn{3}{|c|}{ Type of Workplace (reference: Employer's place of business } \\
\hline Customer's place of business & $1.220^{*}$ & $1.014 \sim 1.466$ \\
\hline In the case of transportation such as cars & .696 & $0.466 \sim 1.040$ \\
\hline Outdoor (construction site, field / etc.) & $1.668^{* *}$ & $1.423 \sim 1.956$ \\
\hline My house & 2.200 & $0.186 \sim 25.995$ \\
\hline
\end{tabular}

Adjusted by Sex, Age, Number of workers in workplace, Work status, need of personal protective equipment, Wage provider and Types of workplace ${ }^{*} p<0.05 * * 0<0.01$ 
wear the personal protective equipment, and the number of night shifts. The rate of exposure to SHS for more than one quarter of working time (ESQ rate) was 16\% for males and $6.9 \%$ for females. By age, the ESQ rate was highest in the $50 \mathrm{~s}$ and by employment status, the ESQ rate was highest for self - employed with workers. Among the wage workers, the ESQ rate was highest for the daily workers, and in terms of the wage-payment method, the ESQ rate was highest for workers who were paid by service companies. In terms of the number of employees at workplaces, the ESQ rate was highest for the companies with less than 50 employees and by types of workplace, the ESQ rate was highest in outdoor work-places, such as construction sites and farms. By types of occupation, the ESQ rate was highest in the functional and related functional staff. The rate of SHS exposure was higher for workers wearing protective gear than for workers not wearing protective gear. A greater- number of night shifts also increased SHS exposure (Table 1).

\section{SHS exposure by job status}

According to the logistic regression analysis (Table 2), the risk of SHS exposure of males was 4.107 times (95\% CI: $3.461 \sim 4.874$ ) higher than that of females. By age groups, exposure for those in their forties was 1.551 times (95\% CI: $1.348 \sim 1.785$ ) and for those in their fifties were 1.529 times (95\% CI: $1.319 \sim 1.772)$ more than for those under 39 years of age. In terms of the number

Table 3 Secondhand smoke exposure affecting by discrimination experience

\begin{tabular}{|c|c|c|c|c|c|}
\hline \multirow[t]{2}{*}{ Variables } & \multirow[t]{2}{*}{$n$} & \multicolumn{3}{|c|}{ Exposure to SHS in Workplace (Number (\%)) } & \multirow[t]{2}{*}{$p$-value } \\
\hline & & Over $1 / 4$ workhours & Almost never & Never & \\
\hline \multicolumn{6}{|c|}{ Age discrimination } \\
\hline Yes & $2473(5.0 \%)$ & $438(17.7)$ & $739(29.9)$ & $1296(52.4)$ & \multirow[t]{2}{*}{$p<0.01$} \\
\hline No & $46,996(95.0 \%)$ & $5546(11.8)$ & $14,291(30.4)$ & $27,159(57.8)$ & \\
\hline \multicolumn{6}{|c|}{ Race discrimination } \\
\hline Yes & $442(0.9 \%)$ & $89(20.1)$ & $131(29.6)$ & $222(50.2)$ & \multirow[t]{2}{*}{$p<0.01$} \\
\hline No & $49,046(99.1 \%)$ & $5913(12.1)$ & $14,883(30.3)$ & $28,250(57.6)$ & \\
\hline \multicolumn{6}{|c|}{ Nationality discrimination } \\
\hline Yes & $417(0.8 \%)$ & $113(27.1)$ & $122(29.3)$ & $182(43.6)$ & \multirow[t]{2}{*}{$p<0.01$} \\
\hline No & $49,081(99.2 \%)$ & $5888(12.0)$ & $14,899(30.4)$ & $28,294(57.6)$ & \\
\hline \multicolumn{6}{|c|}{ Sex discrimination } \\
\hline Yes & $802(1.6 \%)$ & $132(16.5)$ & $240(29.9)$ & $430(53.6)$ & \multirow[t]{2}{*}{$p<0.01$} \\
\hline No & $48,698(98.4 \%)$ & $5859(12.0)$ & $14,803(30.4)$ & $28,036(57.6)$ & \\
\hline \multicolumn{6}{|c|}{ Religion discrimination } \\
\hline Yes & $143(0.3 \%)$ & $13(9.1)$ & $58(40.6)$ & $72(50.3)$ & \multirow[t]{2}{*}{$p<0.01$} \\
\hline No & 49,353 (99.7\%) & $5984(12.1)$ & $14,982(30.4)$ & $28,387(57.5)$ & \\
\hline \multicolumn{6}{|c|}{ Disability discrimination } \\
\hline Yes & $244(0.5 \%)$ & $68(27.9)$ & 77 (31.6) & $99(40.6)$ & \multirow[t]{2}{*}{$p<0.01$} \\
\hline No & $49,197(99.5 \%)$ & $5924(12.0)$ & $14,930(30.3)$ & $28,343(57.6)$ & \\
\hline \multicolumn{6}{|c|}{ Sexual orientation discrimination } \\
\hline Yes & $188(0.4 \%)$ & $34(18.1)$ & $70(37.2)$ & $84(44.7)$ & \multirow[t]{2}{*}{$p<0.01$} \\
\hline No & $49,212(99.6 \%)$ & $5960(12.1)$ & $14,925(30.3)$ & $28,327(57.6)$ & \\
\hline \multicolumn{6}{|c|}{ Academic group discrimination } \\
\hline Yes & $2113(4.3 \%)$ & $299(14.2)$ & $596(28.2)$ & $1218(57.6)$ & \multirow[t]{2}{*}{$p<0.01$} \\
\hline No & $47,262(95.7 \%)$ & $5677(12.0)$ & $14,375(30.4)$ & $27,210(57.6)$ & \\
\hline \multicolumn{6}{|c|}{ Region of origin discrimination } \\
\hline Yes & $820(1.7 \%)$ & $154(18.8)$ & $261(31.8)$ & $405(49.4)$ & \multirow[t]{2}{*}{$p<0.01$} \\
\hline No & $48,610(98.3 \%)$ & $5831(12.0)$ & $14,743(30.3)$ & $28,036(57.7)$ & \\
\hline \multicolumn{6}{|c|}{ Employment status discrimination } \\
\hline Yes & $1593(3.2 \%)$ & $327(20.5)$ & $460(28.9)$ & $806(50.6)$ & \multirow[t]{2}{*}{$p<0.01$} \\
\hline No & 47,782 (96.8\%) & 5659 (11.8) & $14,531(30.4)$ & $27,592(57.7)$ & \\
\hline
\end{tabular}


of workers in the workplace, the risk of exposure to SHS in companies with less than 50 workers was 2.114 times (95\% CI: $1.721 \sim 2.595$ ) higher than that in companies with more than 300 workers and that of daily workers was 1.318 times (95\% CI: $1.102 \sim 1.575)$ higher than that of regular workers. The risk of exposure to SHS for workers receiving wages from the service provider was 1.736 times higher than that for workers receiving wages at work. The risk of exposure to SHS for outdoor workers was 1.668 times higher than for those working at the employer's place of business.

\section{SHS exposure by experience of discrimination at work}

Examining the degree of exposure to SHS in terms of experience of discrimination in the last 12 months in the workplace, showed that workers who have experienced discrimination at work because of age (adjusted OR 1.637, 95\% CI 1.468 1.825), race (adjusted OR 1.850, 95\% CI 1.459 2.347), nationality (adjusted OR 2.699, 95\% CI 2.161 3.371), sex (adjusted OR 1.969, 95\% CI 1.623 2.389), disability (adjusted OR 2.758, 95\% CI 2.069 3.676), sexual orientation (adjusted OR 1.801, 95\% CI 1.231 2.633), academic group (adjusted OR $1.271,95 \%$ CI 1.119 1.443), place of origin (adjusted OR 1.657, 95\% CI 1.384 1.984), or employment status (adjusted OR 2.010, 95\% CI 1.770 2.283) were more exposed to SHS than the counterparts who are not experienced discrimination (Tables 3 and 4).

\section{SHS exposure by occupations}

Occupational groups (classification code: 2 digits) by KSCO were analyzed and classified into 52 groups. Construction and mining-related occupations (49.5\%), metal coremakers-related trade occupations (33.3\%), and transport and machine-related trade occupations (31.4\%) were the highest exposure groups for SHS at the workplace. Public and enterprise senior, legal and administration professional occupations $(0.9 \%)$, education professional and related occupations $(1.7 \%)$, and health, social welfare, and religion-related occupations $(1.7 \%)$ were the lowest in exposure to SHS at the workplace (Table 5).

Specific jobs (classification code: 4 digits) by KSCO were analyzed and classified into 415 jobs. Of these, 151 jobs with 50 or more respondents were analyzed. The top 20 jobs for exposure to SHS for more than a quarter of working time are shown in Table 6. Concretereinforcing iron workers $(53.7 \%)$, plasters $(52 \%)$, construction and mining elementary workers $(49.5 \%)$, construction plumbers (48.9\%), and entertainment facilities workers (47.9\%) were the highest SHS exposure jobs. Among the top 50 jobs, construction jobs accounted for about a dozen (Table 6).

\section{Discussion}

\section{By job status}

In this study, we found that male workers in their $40 \mathrm{~s}$ and 50s, workers employed in workplaces with fewer than 50 employees, daily workers, temporary workers, and people working at the customer's premises or working outdoors had a higher risk of exposure to SHS than the others. The Dutch study reported that workers who were male and low-educated were more likely to be exposed to SHS [8]. The German study reported the aspect of higher SHS exposure in younger age group, but this is dependent on the place of exposure, and exceptionally at workplace, 30-44 years had highest SHS exposure differ by the others such as home, bars, or the house of friend [9]. It is known that blue-collar workers and service workers are more likely to expose the higher rate of SHS occupationally than white-collar workers. These are serious concern because blue collar workers have exposed more often to chemical and dust and SHS related health problems can be synergistically effect with those hazards [10].

Also, we found workers who had experienced discrimination at workplace based on age, race, nationality, gender, disability, academic group, place of origin, or

Table 4 Multiple logistic analysis of factors affecting second hand smoke exposure of discrimination experience

\begin{tabular}{|c|c|c|}
\hline \multirow{2}{*}{$\begin{array}{l}\text { Dependent } \\
\text { variables }\end{array}$} & \multicolumn{2}{|c|}{ OR(Odds Ratio, 95\% Cl) } \\
\hline & Crude OR & Adjusted OR \\
\hline
\end{tabular}

Race discrimination (reference No)

Yes $1.848^{* *}(1.463 \sim 2.335)$

$1.850^{* *}(1.459 \sim 2.347)$

Nationality discrimination (reference $\mathrm{No}$ )

Yes $2.719^{* *}(2.186 \sim 3.380) \quad 2.699^{* *}(2.161 \sim 3.371)$

Sex discrimination (reference No)

Yes $1.444^{* *}(1.196 \sim 1.744) \quad 1.969^{* *}(1.623 \sim 2.389)$

Religion discrimination (reference No)

Yes $\quad 0.748(0.426 \sim 1.315) \quad 0.837(0.473 \sim 1.480)$

Disability discrimination (reference No)

Yes $2.820^{* *}(2.128 \sim 3.736) \quad 2.758^{* *}(2.069 \sim 3.676)$

Sexual orientation discrimination (reference No)

Yes $1.594^{*}(1.098 \sim 2.315) \quad 1.801 *(1.231 \sim 2.633)$

Academic group discrimination (reference No)

Yes $\quad 1.207^{*}(1.065 \sim 1.368) \quad 1.271^{* *(1.119 \sim 1.443)}$

Region of origin discrimination (reference No)

Yes $1.697^{* *(1.421 \sim 2.027)} \quad 1.657^{* *(1.384 \sim 1.984)}$

Employment status discrimination (reference No)

Yes $1.922^{* *}(1.697 \sim 2.178) \quad 2.010^{* *}(1.770 \sim 2.283)$

Adjusted by age and sex

${ }^{*} p<0.05 * * p<0.01$ 
Table 5 Exposure to second hand smoke in workplace by occupation group (Top20)

\begin{tabular}{|c|c|c|}
\hline Occupation Group (Code) $)^{\mathrm{a}}$ & $\mathrm{n}$ & $\begin{array}{l}\text { The rate of exposure SHS in workplace over } 1 / 4 \text { working hours } \\
\text { (Number (\%)) }\end{array}$ \\
\hline Construction and Mining Related Elementary Occupations(91) & 671 & $332(49.5)$ \\
\hline Construction and Mining Related Trade Occupations(77) & 1056 & $433(41)$ \\
\hline Metal Coremakers Related Trade Occupations(74) & 393 & $131(33.3)$ \\
\hline $\begin{array}{l}\text { Wood and Furniture, Musical Instrument and Signboard Related Trade } \\
\text { Occupations(73) }\end{array}$ & 114 & $37(32.5)$ \\
\hline Transport and Machine Related Trade Occupations(75) & 759 & $238(31.4)$ \\
\hline Transport and Leisure Services Occupations(43) & 328 & $101(30.8)$ \\
\hline Wood, Printing and Other Machine Operating Occupations(89) & 290 & $87(30)$ \\
\hline Other Technical Occupations(79) & 259 & $75(29)$ \\
\hline Skilled Forestry Occupations(62) & 12 & $3(25)$ \\
\hline Skilled Fishery Occupations(63) & 73 & $17(23.3)$ \\
\hline Construction, Electricity and Production Related Managers(14) & 181 & $41(22.7)$ \\
\hline Driving and Transport Related Occupations(87) & 2503 & $539(21.5)$ \\
\hline Metal and Nonmetal Related Operator Occupations(84) & 233 & $47(20.2)$ \\
\hline Machine Production and Related Machine Operators(85) & 1069 & $214(20)$ \\
\hline Electric and Electronic Related Trade Occupations(76) & 458 & $89(19.4)$ \\
\hline Chemical Related Machine Operating Occupations(83) & 283 & $54(19.1)$ \\
\hline Video and Telecommunications Equipment Related Occupations(78) & 108 & $20(18.5)$ \\
\hline Police, Fire Fight and Security Related Service Occupations(41) & 401 & $70(17.5)$ \\
\hline Transport Related Elementary Occupations(92) & 713 & $118(16.5)$ \\
\hline Clean and Guard Related Elementary Occupations(94) & 2120 & $341(16.1)$ \\
\hline
\end{tabular}

${ }^{a}$ Korean Standard Classification of Occupation code (2 digit code)

type of employment were more likely to experience a higher rate of exposure to tobacco smoke than were their counterparts who had not experienced discrimination. A recent study reported that exposure to discrimination based on age, academic group or employment status put the workers at a high risk of having a poor well-being [12]. Another study also reported an association between SHS and psychological well-being and emphasized the importance of reducing SHS exposure at the workplace [13]. From these studies, exposure to discrimination and SHS are both significantly more likely to induce a poor well-being than counterparts who were not exposed to discrimination and SHS.

\section{By occupations}

The top ten occupations with the highest SHS exposure were construction and mining-related occupations, construction and mining-related trade occupations, metal coremakers-related trade occupations, wood and furniture, musical instrument, and signboard-related trade occupations, transport and machine-related trade occupations, transport and leisure services occupations, wood, printing and other machine-operating occupations, other technical occupations, and skilled forestry occupations, skilled fishery occupations. The least exposed occupations were public and enterprise senior officers, legal and administrative professions, education professionals, and health, social welfare, and religionrelated occupations. Wortley et al. (2002) [8] compared the levels of serum cotinine in nonsmokers to assess the risk of SHS exposure based on NHANES III (19881994) and found that among 40 occupational groups, the geometric mean of serum cotinine was highest in the waiter and waitress group $(0.47 \mathrm{ng} / \mathrm{mL})$, among seven job categories, the geometric mean of serum cotinine was highest in the device operation, producer, and laborer $(0.22 \mathrm{ng} / \mathrm{mL})$. The research data related SHS exposure by occupation were rare to find, instead we can refer to the smoking rate by occupations. Based on the NHANES(National Health and Nutrition Examination Survey) III in the United States, 1988-1994, smoking rates by occupation showed that material-moving occupations, construction laborers, and vehicle mechanics and repairers had the highest smoking rate, whereas teachers and sales representatives reported that the rate of smoking was low [14]. Smith and Leggat (2007) [15] reported that by job category, smoking was most common among laborers and least common among professionals, managers, or administrators. Occupations with high smoking rates were very similar to 
Table 6 Exposure to second hand smoke in workplace by specified jobs (Top 20)

\begin{tabular}{|c|c|c|}
\hline Specified job (Code) ${ }^{a}$ & $\mathrm{n}$ & The rate of exposure SHS in workplace over $1 / 4$ working hours (Number (\%)) \\
\hline Concrete Reinforcing Iron Workers(7721) & 67 & $36(53.7)$ \\
\hline Plasters(7731) & 102 & $53(52)$ \\
\hline Construction and Mining Elementary Workers(910) & 671 & $332(49.5)$ \\
\hline Construction Plumbers(7921) & 88 & $43(48.9)$ \\
\hline Entertainment Facilities Workers(4323) & 192 & $92(47.9)$ \\
\hline Construction Painters(7736) & 94 & $41(43.6)$ \\
\hline Floor Installers(7734) & 61 & $26(42.6)$ \\
\hline Automobile Mechanics(751) & 418 & $170(40.7)$ \\
\hline Window Chassis Assembers and Installers(7737) & 87 & $35(40.2)$ \\
\hline Construction Carpenters(7724) & 269 & $102(37.9)$ \\
\hline Furniture Makers and Repairers(7302) & 66 & $25(37.9)$ \\
\hline Other Construction Finishing Related Technical Workers(7739) & 99 & $37(37.4)$ \\
\hline Printing Machine Operators(8921) & 170 & $63(37.1)$ \\
\hline Street Stall Salespersons and Vendors(5305) & 79 & $29(36.7)$ \\
\hline Welders(743) & 335 & $122(36.4)$ \\
\hline Cutters(7212) & 68 & $23(33.8)$ \\
\hline Interior Electricians(7622) & 172 & $56(32.6)$ \\
\hline Construction and Mining Related Managers(1411) & 109 & $33(30.3)$ \\
\hline Machine Tool Operators(851) & 344 & $100(29.1)$ \\
\hline Handling Equipment Operators(874) & 239 & $69(28.9)$ \\
\hline
\end{tabular}

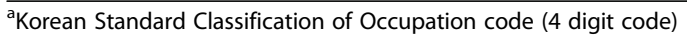

occupations with high SHS rates in our study. Tobacco smoke represents an occupational hazard and a smoke-free environment is an essential component of a healthy and safe. Smith and Leggat [15] reported that smoking rates were higher among unemployed persons in many European countries like France, Italy, and Sweden, the United States and Australia, whereas in Japan, people who were currently employed actually had the higher smoking rates. These results can be affected by different working condition including job status and occupation of each country. Therefore it is necessary to analyze the smoking and SHS exposure rates in job status and occupation for each country.

The strength of this study is to analyze the SHS exposure by job status and occupations and identify the priority group to implement smoking ban policy and confirm the workplace smoking is an occupational health hazard and a smoking ban policy at the workplace is the best option to reduce SHS. But, the limitation of study is that in 4th KWCS data, participant's smoking status was not surveyed and we have not been able to identify how much SHS exposure is affected by whether or not participants are smokers.

\section{Conclusions}

Tobacco smoke is a significant occupational hazard. Smoking cessation ban in the workplace can be a very effective way to reduce the SHS rate in the workplace and can be more effective if specifically designed for the various occupations and working styles in each country. Particularly in South Korea, workers in their 40s and 50 s, workers employed in workplaces with less than 50 employees, daily workers and temporary workers, workers who work outside, and construction workers are priority target for non-smoking regulations at work.

\section{Acknowledgements}

The paper's contents are solely the responsibility of the author and do not necessarily represent the official vies of the OSHRI.

Funding

Not applicable.

\section{Availability of data and materials}

The present study used data from the 4th Korean Working Conditions Survey (KWCS), which was conducted between June and September 2014 on employed workers, 15 years or older by the Occupational Safety and Health Research Institute (OSHRI) affiliated under the Ministry of Employment and Labor. This data is open for anyone to use.

\section{Authors' contributions}

HP analyzed research data, interpretated the result and written this paper, SC made conception and design of this paper and CL double-analyzed and re-checked the data analysis. All authors read and approved the final manuscript.

Ethics approval and consent to participate Not applicable. 


\section{Consent for publication}

Not applicable.

\section{Competing interests}

The authors declare that they have no competing interests.

\section{Publisher's Note}

Springer Nature remains neutral with regard to jurisdictional claims in published maps and institutional affiliations.

Received: 20 June 2018 Accepted: 17 January 2019

Published online: 28 January 2019

\section{References}

1. Jain RB. Exposure to second hand smoke at home and work among nonsmokers. Chemosphere. 2015;135:225-32.

2. National Health Statistics for 2015 (National Health Effects Survey, Phase 6, Third Year Data), Disease Control Headquarters. https://knhanes.cdc.go.kr/ knhanes/sub01/sub01_05.jsp\#s5_01_01. Accessed 15 Aug 2018

3. OECD Data; Health at a glance (2017). https://data.oecd.org/healthrisk/dailysmokers.htm. Accessed 15 Aug 2018.

4. National Health Promotion Act, Article 9 (Date 31, Dec, 2011). https://elaw. klri.re.kr/eng_service/lawView.do?hseq=43278\&lang=ENG.

5. Pickett MS, Schober ES, Brody DJ, Curtin LR, Giovino GA. Smoke-free laws and secondhand smoke exposure in US non-smoking adults, 1999-200. Tobacco Control. 2006;15(4):302-7.

6. State Smoking CDC. Restrictions for private-sector worksites, restaurants, and bars. Oncol Times. 2006;28(1):32-4.

7. Arheart KL, Lee DJ, Dietz NA, Wilkinson JD, Clark JD. Declining trends in serum cotinine levels in US worker groups: the power of policy. J Occup Environ Med. 2008;50(1):57-63.

8. Wortley PM, Caraballo RS, Pederson LL, Pechacek TF. Exposure to secondhand smoke in the workplace: serum cotinine by occupation. J Occup Environ Med. 2002;44(6):503-9.

9. Fischer F, Kraemer A. Factors associated with secondhand smoke exposure in different setting: results from the German health update(GEDA) 2012. BMC Public Health. 2016:16:327-36.

10. Howard J. Smoking is an occupational hazards. Am J Ind Med. 2004;46(2):161-9.

11. Verdonk-Kleinjan WM, Knibbe RA, Tan FE, Willemsen MC, de Groot HN, de Vries $\mathrm{H}$. Does the workplace-smoking ban eliminate differences in risk for environmental tobacco smoke exposure at work? Health Policy. 2009;92(2-3):197-202.

12. Lee HS, Kim GH, Jung SW, Lee JH, Lee KJ, Kim JJ. The association between perceived discriminations and well-being in Korean employed workers: the 4th Korean working conditions survey. Ann Occup Environ Med. 2017;29:46.

13. Kim SJ, Lamichhane DK, Park SG, Lee BJ, Moon SH, Park SM, Jang HS, Kim HC. Association between second-hand smoke and psychological well-being amongst non-smoking wageworkers in Republic of Korea. Ann Occup Environ Med. 2016;28:49.

14. Bang KM, Kim JH. Prevalence of cigarette smoking by occupation and industry in the United States. American J Industrial Medicine. 2001;40:233-9.

15. Smith DR, Leggat PA. Tobacco Smoking by occupation in Australia; results from the 2004 to 2005 National Health Survey. J Occup Environ Med. 2007;49:437-45

Ready to submit your research? Choose BMC and benefit from:

- fast, convenient online submission

- thorough peer review by experienced researchers in your field

- rapid publication on acceptance

- support for research data, including large and complex data types

- gold Open Access which fosters wider collaboration and increased citations

- maximum visibility for your research: over $100 \mathrm{M}$ website views per year

At $\mathrm{BMC}$, research is always in progress.

Learn more biomedcentral.com/submissions 